\title{
Supervisionens organisering
}

\author{
TINE EGELUND \& ANITA KVILHAUG
}

\begin{abstract}
Artiklen beskriver og analyserer anvendelsen af supervision i Individ- og familieomsorgen på baggrund af en statistisk undersøgelse af 70 svenske kommuner, der er reproesentative for landet som helhed. Der fokuseres på supervisionens omfang, kriterier for valg af supervisorer, mäl med supervisionen, supervisionens kvalifikationsudviklende virkninger og supervisionspolicy i IFO. Denne artikel bygger på spørgeskemaer til arbejdslederne for børn og unge-, socialbidrags- og misbrugsarbejde i de 70 kommuner. Der loegges specielt voegt på at diskutere $i$ hvilken grad socialforvaltningsorganisationen anvender supervision målrettet som en integreret del af organisationens kvalifikationsudviklingstrategier.
\end{abstract}

\section{Indledning}

Denne artikel omhandler supervision (handledning $)^{1}$ af socialt arbejde i Individ- og familieomsorgen (IFO). Artiklen er led i publikationen af et større statistisk studie om supervisionens omfang og karakter i kommunernes sociale arbejde og om arbejdslederes, supervisorers og superviseret personales syn på supervision i socialforvalt-

Tine Egelund, socialrådgiver, fil.dr. og docent i socialt arbejde. Tidligere ansat som projektleder ved Centrum för utvärdering av socialt arbete, Stockholm. $\mathrm{Nu}$ anställd som seniorforsker ved Socialforskningsinstituttet, København.

Anita Kvilhaug är utbildad psykolog och arbetar f.n. i Norge. ningsorganisationen. Studiet omfatter også en analyse af svenske postgraduale supervisionsuddannelser på 30 points $^{2}$ (Egelund, 1999).

Trods at supervision som efteruddannelsesform er lige så gammel som socialt arbejde selv (Austin, 1963; Vargus, 1977), at

1 Termen "supervision" anvendes her synonymt med den svenske term "handledning" og den norske "veiledning", idet man på dansk bruger det amerikanske ord uden en fordanskning. Der er ikke med anvendelsen af termen tilstræbt en markering af en forståelse af supervision i overensstemmelse med amerikansk supervisionsteori.

2 I Göteborg, Umeå og på Sköndal. 
supervision er en udbredt strategi for kvalifikationsudvikling i praksis, og at mange efterspørger supervision som en støtte til det daglige arbejde, er der i Norden stort set ikke forsket empirisk om supervision og supervisionens rolle i kvalifikationsudviklingen ${ }^{3}$. Der vides således stort set ingenting om supervisionens omfang; dens mål, indhold og resultater; dens teoretiske fundament; dens rolle i socialforvaltningsorganisationen m.v. Det er baggrunden for, at vi ved Centrum för utvärdering av socialt arbete (CUS), Socialstyrelsen i Stockholm, har taget initiativ til at udforske supervisionsanvendelsen i IFO.

Supervision er en efteruddannelsesaktivitet, der er interessant ud fra flere perspektiver. Der er idag betydelig opmærksomhed på at kundskabsforankre det sociale arbejde, dvs. at skabe grundlag for, at socialt arbejde i højere grad baseres på videnskabelig kundskab og systematiseret/ evalueret praksiserfaring(Wigzell \& Pettersson, 1999). Supervision kan være et gunstigt redskab i en stigende kundskabsforankring, idet supervisionen retter sig mod et mangefacetteret praksisfelt, der dagligt konfronteres med varierede kundskabsbehov, både for klientorienteret kundskab til forståelse af klienters sociale situation og metodeorienteret kundskab om arbejdsmåder, der har sandsynlighed for at få positive effekter for klienterne. Supervision er også tæet knyttet

3 Der er dog få undersøgelser med et evaluerende sigte. To vedrører supervisionsuddannelser (Fryk \& Skårner, 1983; Hessle \& Höjer, 1979). En undersøgelse vedrører en bestemt supervisionsmodels tillempning til praksis (Bernler \& Johnsson, 1988 a). En (Forslin, 1986) vedrører kortlægning af supervisionsbehov i 3 län. til problemer, som socialarbejderen oplever i sit daglige arbejde, hvilket kan give supervision en unik mulighed for at tage fat i de sværeste praksiskonflikter, der kan blokere for et hensigtsmæssigt socialt arbejde i forhold til klienterne. Supervision er desuden vigtig, fordi den er en "demokratisk» efteruddannelsesform, der tilbyder personalet en løbende kompetence-udvikling som led i deres daglige arbejde. Dvs. at supervision kan nå mange socionomer, som af forskellige grunde i begrænset omfang har mulighed for at deltage $i$ andre efter- og videreuddannelsesaktiviteter. Endelig får supervision aktuelt en specifik interesse, fordi SSR tillægger den særlig betydning i autorisation af socionomer, idet supervision er det eneste krav til postgradual kompetenceudvikling, som autorisationskriterierne stadfæster.

Denne artikel koncentreres om det syn på supervision, som arbejdsledere i IFO har præsenteret via spørgeskemaer. Arbejdsledere personificerer i denne undersøgelse socialforvaltningsorganisationen, idet de forventes at repræsentere de organisatoriske interesser, ledere skal varetage. Derfor fokuserer artiklen på supervisionens rolle i organisationen, for eksempel organisationens indflydelse på supervisionens indhold, organisatoriske kriterier for valg af supervisorer, organisatorisksupervisionspolicy m.m. I en senere artikel vil uddannelsesmæssige perspektiver på supervision blive præsenteret via det billede af supervisionen, dens mål, indhold og teoretiske forankring, som supervisorer og superviseret personale informerer om i de spørgeskemaer, de har besvaret.

Egelund, T. \& Kvilhaug, A.: Supervisionens organisering 


\section{Materiale og metode}

Undersøgelsen arbejder med et stratificeret udvalg af 70 svenske kommuner ${ }^{4}$. Indenfor de 70 kommuner ønskede vi at identificere samtlige mellemledere, der var 1) arbejdsledere for IFO's kærneområder: socialbidrag, børn- og ungearbejde og misbrugsarbejde. Desuden ønskede vi 2) at identificere ledere for "ambulante" aktiviteter indenfor disse tre kærneområder (ydelsesformidling, rådgivning, behandling, udredning, myndighedsudøvelse m.v.), mens vi udelod de forskellige typer af institutionsforsorg, mange kommuner har etableret.

Denne identificeringsopgave viste sig at være et kompliceret arbejde, idet ikke to kommuner har organiseret sig ens. Der er ligeså mange variationer af organisatoriske modeller, som der er kommuner, og iblandt var modellerne så komplicerede, at det var vanskeligt at få et billede af, hvordan organisationens forskellige dele hang sammen ${ }^{5}$. Der kan på denne baggrund, trods grundige

4 Udvalget baseres på, at samtlige svenske kommuner (efter kommuneinddelingen i 1994) er placeret i 3 strata. I stratum 1 indgår Stockholm, Göteborg og Malmö, i stratum 2 kommuner med flere end 30000 indbyggere og i stratum 3 kommuner med færre end 30000 indbyggere. Fra stratum 1 indgår alle tre kommuner i udvalget. I de øvrige strata er et slumpmæssigt udvalg af kommuner foretaget (32 i stratum 2 og 35 i 3). Stratificeringen er baseret på Svenska Kommunförbundets kommunegruppering, som udgårfra folketal, beliggenhed, bebyggelsesgrad, indbyggere pr. km2 og erhvervsstruktur. Desuden er kommunerne grupperet efter, om der var flere eller færre end 30000 indbyggere ifølge folketællingen (FOB) 1990.

5 Der var også forskelle på, hvilke virksomheder, der overhovedet var omfattet af IFO (nogle kom- overvejelser i hvert enkelt tvivlstilfælde, ikke bortses fra, at relevante virksomheder i enkelte tilfælde er blevet bortvalgt, eller at ikke relevante virksomheder er taget med i undersøgelsen.

Ved dette forarbejde identificeredes i de 70 kommuner 478 relevante arbejdsledere, som fik tilsendt spørgeskemaer ${ }^{6} .412$ arbejdsledere returnerede spørgeskemaet, hvilket udgør en svarfrekvens på 86 procent ${ }^{7}$. På grund af systematisk komplettering af utilstrækkeligt udfyldte spørgeskemaer, forekommer internt bortfald næsten ikke i undersøgelsen.

For at kunne lave en for hele landet dækkende kortlægning, blev materialet vægtet

muner havde for eksempel åben modtagelse for misbrugere eller flygtninge, andre ikke, ligesom diverse forskellige projekter er etableret i kommunerne). Det varierede yderligere, hvilke betegnelser, man i forskellige kommuner anvendte for samme virksomhed (for eksempel kan socialbidrag hedde "försörjningsstöd", "ekonomi", sysselsättning« m.v.). Den store opgave blev derfor via telefonkontakt til de 70 kommuner at inkludere for undersøgelsen relevante og udskille irrelevante virksomheder/aktiviteter. I nogle tilfælde måtte relevansen afgøres via et skøn, som vi valgte at gøre liberalt i den forstand, at vi medtog en virksomhed, hvis blot en del af dens aktiviteter faldt indenfor vore kriterier.

6 Spørgeskemaet udarbejdedes med konsultativ støtte fra Socialstyrelsens statistikafdeling. Spørgeskemaerne var primært baserede på spørgsmål med faste svaralternativer. Nogle svar var imidlertid åbne, og svarene på dem kategoriseredes efterfølgende af os.

7 Der er begrænsede muligheder for at analysere bortfaldet på 14 procent. Det falder skævt indenfor de tre strata, idet 38 procent af bortfaldet forekommer i stratum 1, 62 procent i stratum 2. 
proportionelt med hjælp af statistisk expertice.

Det indsamlede materiale er omfattende, og for at kunne præsentere det oversigtligt er der foretaget to typer af analyser: frekvensfordelinger og bivariate krydstabuleringer. Disse typer af forholdsvis enkle analyser svarer til undersøgelsens primært beskrivende og kortlæggende kundskabsinteresse. Forskelle i fordelingen af variable testes ikke med signifikanstester, der vil i stedet blive lagt vægt på analyse af åbenbare forskelle ${ }^{9} \mathrm{i}$ materialet.

En spørgeskemaundersøgelse som denne er underkastet nogle begrænsninger i forhold til, hvilken type af kundskab, den kan frembringe. Den kan give et landsdækkende "øjebliksfotografi" af forekomsten af en række relativt håndfaste variable, knyttet til supervision, for eksempel det samlede omfang af anvendelse af supervision, kommuners tilbøjelighed til at udforme formelle policydokumenter om supervision m.m. Ogsåforekomsten af mindrehåndfaste

8 Dette indebærer at resultaterne er repræsentative for Sverige som helhed. Vægtningen indebærer, at stratum 1 er givet mindre vægt og stratum 2 og 3 mere. Materialet vægtedes siden op til nationalt niveau. Til vægtningen anvendtes formelen: $((\mathrm{a} / \mathrm{b}) /(\mathrm{c} / \mathrm{d}))$ hvor a = skønnet totalantal af populationen indenfor respektive stratum, $\mathrm{b}=$ antal, som har besvaret spørgeskemaet indenfor respektive stratum, c = skønnet totalpopulation og $\mathrm{d}=$ antal, som har besvaret spørgeskemaet totalt.

9 Der er ikke regnet konfidensintervaller på samtlige resultater. Resultaterne er tolket i lys af, at man statistisk bør regne med konfidensintervaller på $+/-5$ procent, når det drejer sig om hele den undersøgte gruppe og på $+/-10$ procent, hvis materialet brydes ned i undergrupper. fænomener af betydning for supervisionen og dens indhold kan opfanges via spørgeskemaer, for eksempel forskellige hensigter/mål medsupervisionen, supervisorersforskellige teoretiske inspirationer, forskellige opfattelser af supervisionens anvendelighed i det daglige arbejde m.v. Spørgeskemasvar kan imidlertid ikke belyse, hvilke komplekse processer der foregår i supervisionslokalerne, og end mindre hvordan de i supervisionen opnåede indsigter påvirker kvaliteten i klientarbejdet. Hvis komplekse processer skal blotlægges, må andre metoder bringes $i$ anvendelse til fordybelse af den oversigtlige viden, der er denne undersøgelses styrke.

\section{Resultater}

\section{Kort karakteristik af arbejdslederne}

Indledningsvist skal arbejdsledergruppen præsenteres ud fra nogle grundlæggende karakteristika som køn, alder, grund- og videreuddannelse.

Kønsfordelingen blandt arbejdslederne var 67 procent kvinder och 33 procent mænd. Hvad angår aldersfordelingen er arbejdsledernes alder relativt høj, idet 86 procent af arbejdslederne er 41 år eller ældre, de 35 procent er mere end 51 år.

Som forventet var de allerfleste af arbejdslederne grunduddannet som socionomer, 87 procent $^{10}$. Det fremgår yderligere af svarene,

\footnotetext{
10 For de, som havde en anden akademisk grunduddannelse, drejede det sig om psykologuddannelse, fil.kand. e.l.
}

Egelund, T. \& Kvilhaug, A.: Supervisionens organisering 
at halvdelen af arbejdslederne tog deres eksamen for 20 år siden eller mere, altså $\mathrm{i}$ 70'erne. En meget lille del af arbejdslederne har en uddannelse, som er yngre end 10 år, sammanlagt 7 procent.

Med hensyn til akademisk uddannelse udover grunduddannelsen har 4 procent af arbejdslederne en magisteruddannelse, 9 procent har en statslig psykoterapeutisk videreuddannelse (trin 1 eller trin 2), 36 procent angav, at de havde opnået akademiske points efter grunduddannelsen, oftest i form af enkeltstående kurser.

Der blev også spurgt, om arbejdslederne havde gennemgået andre efter-/videreuddannelser, for eksempel i form af intern efteruddannelse ${ }^{11}$. Det almindeligste er, at arbejdslederne ikke har sådan efter-/ videreuddannelse (62 procent). Andre videreuddannelser fordeler sig indholdsmæssigt således, at 30 procent vedrører psykoterapeutisk teori/metode, 20 procent indlæring af en specifik arbejdsmetode, 20 procent en eller anden form for supervisions-uddannelse ${ }^{12}, 15$ procent efteruddannelse om arbejdsledelse og 15 procent andet (for eksempel juridiske spørgsmål og sagsbehandling).

Karakteristisk for arbejdslederne er desuden, at de har høj ansaettelsesanciennitet $\mathrm{i}$ IFO, 76 procent har været ansat i elleve eller flere år. De har derimod ikke lang anciennitet som ledere i den aktuelle stilling, 63 pro-

11 For at sætte en »bagatelgrænse» udelukkede vi efteruddannelse af en samlet varighed af under 4 uger.

12 Ofte i form af uddannelse om supervision af praktikanter. 2 af de 20 procent angav at have supervisionsuddannelser på 30 points. cent har været i deres lederjob i 4 år eller derunder.

Arbejdslederne fordeler sig på virksomhedsområderne indenfor IFO således, at 20 procent er arbejdsledere for socialbidrag, 21 procent for børn og unge, 13 procent for misbrug og 40 procent for blandede grupper, der integrerer forskellige kombinationer af de tre virksomhedsområder ${ }^{13}$. Det hyppigst forekommende er, at arbejdslederne har mellem 6 og 10 personer under sig indenfor ledelsesområdet (38 procent), den næsthyppigste størrelse på personalgruppen er mellem 11 og 15 personer (27 procent), 13 procent af arbejdslederne leder grupper på 5 personer eller mindre.

Sammenfattende er der overvejende tale om kvindelige, midaldrende ledere, der har en relativt gammel socionomeksamen. 49 procent har en eller anden form for kortere eller længerevarende akademisk overbygning på grunduddannelsen. 62 procent har ikke efter-og videreuddannelse af mere end 4 ugers varighed af anden karakter end akademisk videreuddannelse. Akademisk og anden videreuddannelse vedrører forskellige emner, men en relativt stor andel af videreuddannelsesforløbene vedrører psykoterapeutiske emner.

Mange arbejdsledere har videreuddannelse, men for gruppen som helhed er videreuddannelsesniveauet relativt begrænset $\mathrm{i}$ lys af længden af deres erhvervsaktive liv. Til gengæld ser arbejdslederne ud til at have lang erfaring fra praksis i IFO. Man kan få det indtryk, at de er vokset op til lederskabet

136 procent er arbejdsledere for "andet«, hvilket må ses som en konsekvens af det organisatoriske panorama, beskrevet ovenfor. 
gennem mange års ansættelse indenfor socialforvaltningsarbejde. Denne uddannelsesog erfarings-profil kan tænkes at få indflydelse på, hvilke kvalifikationer hos personalet, arbejdslederne er veludrustede til at styrke, og hvilke der må styrkes ved andre påvirkninger end arbejdsledelsens. Det er nærliggende at tænke sig, at mange arbejdsledere først og fremmest kan styrke personalet på baggrund af deres langvarige kendskab til og indsigt i socialforvaltningens arbejdsopgaver og virkemåde og måske i mindre grad kan formidle kundskaber af den karakter, som formel videreuddannelse bibringer.

\section{Supervisionens omfang}

Arbejdslederne i de 70 kommuner opgav, at de sammenlagt havde 4416 personalemedlemmer under sig, heraf havde 3587 supervision på undersøgelsestidspunktet, dvs. 81 procent. Der fandtes totalt 550 supervisionsgrupper i de 70 kommuner. Der var næsten udelukkende tale om, at personalet fik gruppesupervision (93 procent). I forhold til 6 procent af personalet forekommer både individuel og gruppesupervision, kun 1 procent får udelukkende individuel supervision. En beregning af, hvor stor en del af personalegrupperne i hvert virksomhedsområde (socialbidrag, børn og unge, misbrug) der får supervision ${ }^{14}$, viser, at børn- og ungegrupper får supervision i relativt størst

14 I beregningen forsvinder kategorien "blandingsgrupper", fordi den er opløst i de relevante undergrupper. Hvisarbejdslederen for eksempel ledede en misbrugsgruppe, kodedes det ind, om gruppen modtog supervision. Hvis der var tale om en blandingsgruppe, for eksempel børn og omfang (83 procent), og socialbidragsgrupper i mindst (73 procent $)^{15}$. Misbrugsgrupper placerer sig i en mellemposition (77 procent). Personalegrupper i samtlige virksomhedsområder tilbydes dog i meget stort omfang supervision.

Ressourceforbruget til supervision er søgt kortlagt, såvel i forhold til, hvad supervisionen koster, som til det tidsforbrug, der medgår til supervisionen.

Arbejdslederne blev bedt om at tilkendegive, hvor mange penge, der anvendtes på supervision indenfor deres ledelsesområde, dvs. indenfor mellemlederens eget domæne, i hele kalenderåret 1997. 46 procent af arbejdslederne angiver, at der anvendtes op til $50.000 \mathrm{kr}$. indenfor deres område, 32 procent angav, at der var anvendt 51.000 eller derover (heraf markerede 5 procent et forbrug på mellem 76.000-100.000, og 6 procent et forbrug på over $101.000 \mathrm{kr}$.). 22 procent kendte ikke forbruget på deres område i 1997. Disse tal antyder, at der kan være tale om et relativt stort kommunalt ressourceforbrug til supervision ${ }^{16}$. Arbejdslederne er desuden spurgt om, hvor lang tid et supervi-

unge/misbrug, kodedes det, om børn og unge, misbrug eller begge områder modtog supervision.

15 Bergmark \& Lundström (1998) og Dellgran \& Höjer (1999) viser, at forsørgelses- og socialbidragsområdet er underprioriteret i socionomuddannelsen på grundniveau. Det samme kunne se ud til at være tilfældet på det efteruddannelsesniveau, som supervision repræsenterer.

16 Ressourceforbruget til andre typer af efter- og videreuddannelse kendes ikke, så det er ikke muligt at afgøre, om supervision er en priviligeret efteruddannelsesaktivitet i forhold til andre efteruddannelsesmuligheder.

Egelund, T. \& Kvilhaug, A.: Supervisionens organisering 
sionsforløb finder sted. Det almindeligste er, at supervisonen forløber af over et års varighed (44 procent af forløbene), det næsthyppigste er forløb af en varighed på mellem $1 / 2$ og 1 år (32 procent). Supervision foregår således som hovedregel over et relativt langstrakt forløb.

I de fleste tilfælde mødes supervisor og supervisionsgruppe hver 14. dag (74 procent) til et møde, der i de fleste tilfælde er af 2-3 timers varighed ( 55 procent). Uden at regne videre på disse tal er det klart, at en supervisionsgruppe tilsammen anvender flere arbejdsuger over et år til supervision. For den enkelte er det dog et overskueligt tidsforbrug, der medgår til supervision.

Supervision som efteruddannelsesaktivitet må sammenfattende siges at være prioriteret højt i kommunerne. 81 procent af personalet får supervision af en varighed, som for langt de flestes vedkommende overstiger $1 / 2$ år pr. supervisionsforløb ${ }^{17}$. Den samlede tid, der medgår til den løbende supervision, er ikke ganske ubetydelig, selvom den enkelte medarbejders tidsforbrug er overskueligt. Arbejdsledernes oplysninger om forbruget af penge til supervision antyder, at der kan være tale om relativt store beløb på landsplan. Man kan på denne baggrund sige, at svenske kommuner på supervisionsområdet lægger vægt på at investere i dygtiggørelsen af deres personale ${ }^{18}$.

17 Af det superviserede personales spørgeskemaer er der grund til at tro, at et afsluttet supervisionsforløb ofte ersattes af igangsættelse af det næste, idet en stor andel af personalet angiver at have haft et flertal af supervisorer.

18 Supervision er ikke den eneste måde, på hvilken kommunerne søger at udvikle personalets kvalifikationer. Arbejdslederne blev bedt om at

\section{Udvaelgelse af supervisorer}

Identificeringen af, hvem der er centrale $\mathrm{i}$ udvælgelsen af supervisorer, kan sige noget om, i hvor høj grad organisationen via sine ledere lægger vægt på at bestemme, hvilke supervisorer der er relevante i forhold til organisationens behov. De kriterier, der lægges til grund for udvælgelsen, kan illustrere de kvaliteter ved supervision eller den supervisionsprofil, der efterspørges. Udvælgelsen af supervisorer har været genstand for interesse i undersøgelsen. Arbejdslederne blev således spurgt om både hvem, som deltager i udvaegelsesprocessen af supervisorer, og hvilke kriterier, der loegges til grund for valget af en supervisor.

Spørger man, hvem som tog initiativet til etablering af supervisionen, hvem som kontaktede supervisor og besluttede, hvem som skulle ansættes, bliver det klart, at personalet er meget aktiv i processen. I 54 procent af tilfældene var personalet involveret $i$ at tage initiativ til supervisionen og i 66 procent $i$ at beslutte, hvilken supervisor som skulle ansættes, enten alene eller sammen med arbejdslederen. Oftest er det arbejdsledelsen, som kontakter supervisor, men personalet er også aktivt.

angive, hvilke andre typer af kvalifikationsudvikling, der foregik under deres ledelsesområde. 32 procent nævnte afholdelse af interne kurser, som hyppigst omhandlede fælles indlæring på arbejdspladsen af en bestemt arbejdsmetode. 82 procent nævnte personalets deltagelse i konferencer, 42 procent studierejser, 36 procent afholdelse af enkeltforelæsninger, 22 procent konsultativ støtte til vanskelige sager, og 14 procent nævnte p-grupper. 


\begin{tabular}{|c|c|c|c|}
\hline Tabel I & & & \\
\hline $\begin{array}{l}\text { Hvem tog initiativet til, at supervisio } \\
\text { hvem der skulle ansaettes? }\end{array}$ & nen kom iga & kontaktede s & rvisor og besluttede, \\
\hline & $\begin{array}{l}\text { Tog initiativet } \\
\qquad N=332\end{array}$ & $\begin{array}{r}\text { Kontaktede } \\
\text { supervisor } \\
N=332\end{array}$ & $\begin{array}{r}\text { Besluttede } \\
\text { ansættelse } \\
\mathrm{N}=332\end{array}$ \\
\hline Det superviserede personale & $32 \%$ & $30 \%$ & $38 \%$ \\
\hline Arbejdslederen & $23 \%$ & $35 \%$ & $12 \%$ \\
\hline Arbejdslederen sammen med personalet & $22 \%$ & $5 \%$ & $28 \%$ \\
\hline Andre i arbejdsledende stilling & $15 \%$ & $23 \%$ & $15 \%$ \\
\hline Ved ikke & $8 \%$ & $7 \%$ & $7 \%$ \\
\hline
\end{tabular}

Sammenfattende udviser personalet megen aktivitet i forbindelse med initiativ til supervision og beslutning om ansættelse af en bestemt supervisor i samarbejde med arbejdslederen eller andre i ledende stilling. Mest aktivt er personalet $\mathrm{i}$ beslutninger om ansættelse af supervisor. Det kunne tolkes på den måde, at man i særlig grad organisatorisk lægger vægt på, at personalet har tillid til og godkender, hvem de skal have som supervisor. Det ser ud, som om etablering af supervison er en delt aktivitet mellem ledelse og personale, i hvilken der råder en accept af en bottom-up deltagelse i, om der skal være supervision og ved hvem. Personalets aktivitet kan også tolkes som en markeret interesse hos personalet for, at supervision etableres.

Med hensyn til de kriterier, der lægges til grund for valget af en supervisor, er tre dimensioner undersøgt: 1) en dimension, som vedrører formelle professionelle kvalifikationer, forankret i supervisors uddannelsesbaggrund eller teoretiske orientering, 2) en dimension, som vedrører supervisors kendskab til eller egen praksiserfaring fra
IFO, 3) samt en dimension som handler om supervisors personlige egenskaber, for eksempel "god personkemi« eller personligt kendskab til supervisor.

Formelle professionelle kvalifikationer. Supervisors formelle uddannelsesbaggrund havde begrænset vægt $i$ valget af supervisorer. 79 procent af arbejdsledere angav, at der ikke var lagt vægt på supervisors grunduddannelsesbaggrund ${ }^{19} .85$ procent havde ikke tillagt videreuddannelse vægt, 10 procent efterspurgte legitimerede psykoterapeuter og 5 procent anden videreuddannelse $(0$ procent efterpurgte magisteruddannelse $i$ socialt arbejde). 81 procent af arbejdsledere oplyste, at der ikke lagdes vægt på supervisionsuddannelse ved valget af supervisor. Arbejdsledere, der selv har gennemgået supervisionsuddannelser lægger sjældnere (14 procent) vægt på, at supervisorer er supervisionsuddannede, end arbejdsledere, der ikke har supervisionsuddannelse (23 procent).

19 I de 21 procent, hvor man lagde vægt på grunduddannelse, foretrak man nogenlunde ligeligt socionomer og psykologer.

Egelund, T. \& Kvilhaug, A.: Supervisionens organisering 
Man kan på denne baggrund konstatere, at udvælgelseskriterierne i begrænset grad vedrører formel uddannelse. Det mest specifikke er, at et lille mindretal (10 procent) efterspørger legitimerede psykoterapeuter, og at det i 19 procent af tilfældene er fundet relevant, at supervisor har nogen form for supervisionsuddannelse. Ved bivariate analyser fremtræder der ikke væsentlige forskelle på, hvilken grund- eller videreuddannelse arbejdsledere selv har, eller hvilke virksomhedsområder, de er ledere for. Undtagelsen er det ovennævinte lidt paradoksale fund, at arbejdsledere uden supervisionsuddannelse tillægger supervisors supervisionsuddannelse større betydning end arbejdsledere, der selv har gennemgået supervisionsuddannelse. Ser man på uddannelse som helhed (grund-, videre- og supervisionsuddannelse), er det 61 procent af arbejdslederne, der angiver, at uddannelse ikke er indgået som et kriterium i udvælgelsen af supervisorer.

Supervisors specifikke teoretiske/metodiske orientering har for et flertal (62 procent) af arbejdsledernes vedkommende ikke spillet nogen rolle som kriterium for udvælgelsen af supervisorer. Teoretiske orienteringer, som tillagdes vægt i udvælgelsen var systemteori (11 procent angav dette som et kriterium), psykodynamisk teori (7 procent), løsningsfokuseret teori (7 procent) og andet (for eksempel netværksorienteret teori) (13 procent). Der var nogen forskel mellem arbejdsområder. Socialbidrag lagde sjældnere vægt på teoretisk orientering end andre virksomhedsområder, men betonede oftere løsningsfokuseret teori, når de gjorde det. Børn og unge-enheder lagde mest vægt på systemteori, mens misbrugsenhe- der betonede psykodynamisk og løsningsfokuseret teori i nogenlunde lige høj grad.

Sammenfattende kan man sige, at bestemte teorier/metoder og det, de forventes at kunne tilføre det specifikke arbejdsfelt, kun i begrænset omfang har været lagt til grund for valget af supervisorer. Det vil sige, at professionelle kriterier (supervisors uddannelse, videreuddannelse, supervisionsuddannelse og specielle kyndighed $i$ en praksisteoretisk referenceramme) ikke vejer tungt, når man bestemmer sig for anvendelsen af en given supervisor i kommunen.

Kendskab til IFO og egen praksiskompetence. Dette kriterium er mindre formelt og refererer til et kendskab til IFO's arbejde (for eksempel fra tidligere virksomhed som supervisor) eller til, at supervisor anses for selv at besidde kompetence fra socialt arbejde. Arbejdslederne angiver, at der har været lagt større vægt på disse mere erfaringsorienterede kriterier end på formelle professionelle kriterier. 47 procent har lagt vægt på, at supervisor har kendskab til IFO, og 37 procent har i valget lagt vægt på, at supervisor selv er en kompetent praktiker i socialt arbejde. Ser man på disse erfaringsorienterede kriterier under et, har 60 procent af arbejdslederne lagt vægt på at anvende mindst et af dem i udvælgelsen af supervisorer. Der er nogle forskelle mellem virksomhedsområderne, idet socialbidrags- og misbrugsenheder oftere lægger vægt på, at supervisor selv er en kompetent praktiker indenfor socialt arbejde, mens børn- og unge-enheder betoner kendskabet til IFO.

Sammenfattende lægges der i valget af supervisorer vægt på erfaringsbaserede kriterier i form af kendskab til arbejdsområdet 
og af, at supervisor anses for selv at mestre praksis i socialt arbejde.

Personlige egenskaber indgår som et kriterium i valget af supervisor. Kriterier som "personligt kendskab" til pågældende og "god personkemi" har været udslaggivende $i$ en del beslutninger om, hvem der skal anvendes som supervisor (henholdsvist 38 procent og 33 procent). Under et lægger 61 procent af arbejdslederne vægt på personorienterede kriterier i udvælgelsen af supervisorer. Der er ikke nævneværdige forskelle mellem virksomhedsområder i denne henseende.

Sammenfattende angives tidligere kendskab til og sympati for supervisor og tillid til supervisors personlige kapacitet og dygtighed ofte som begrundelse for valget af ham/ hende.

\section{Arbejdsledernes mål med supervisionen}

I spørgeskemaet er arbejdslederne spurgt, hvilke mål supervisionen faktisk opfylder. De er yderligere blevet spurgt om, hvilke mål de sigter på med deres egen arbejdsledende vejledning af personalet. Arbejdsledernes opfattelser af supervisionens målopfyldelse kan samles i 3 kategorier: 1) en som handler om at styrke specifikke professionelle kvalifikationer (metodeudvikling, formidling af teori og forskningsresultater m.m.), 2) en som er orienteret mod personalets personlige udvikling og personalepleje (forebyggelse af stress og udbrændthed, styrkelse af personalets bevidsthed om sig selv m.m.) og 3) en som er klientorienteret (øge forståelsen for klienternes situation m.m.).

De mål, som arbejdslederne finder, at supervisionen faktisk opfylder, identificeredes via lukkede svarkategorier, af hvilke arbejdslederne kunne markere så mange, de fandt relevante.

Tabellen (Tabel 2) viser først og fremmest, at arbejdslederne peger på, at supervisionen opfylder flere samtidige mål. Mange arbejdsledere mener, at supervisionen både imødekommer behov for at styrke faglige kvalifikationer, at modvirke psykisk nedslidning af personalet, at øge selvindsigt og at forstå klienters situation bedre. Der er en

\footnotetext{
Tabel 2

Hvilke mål opfylder supervisionen efter arbejdsledernes opfattelse?

Professionelle mål: $\quad \mathrm{N}=333$

Leder til udvikling af profesionelle arbejdsmetoder og korrekt sagsbehandling $\quad 78 \%$

Leder til øget kundskab om teori og forskning $\quad 32 \%$

Personaleplejende/personlighedsudviklende mål:

Leder til øget indsigt i sig selv $96 \%$

Udgør en følelsesmæssig støtte og modvirker stress/udbrændthed $\quad 85 \%$

$\begin{array}{ll}\text { Forbedrer gruppesamarbejdet } & 70 \%\end{array}$

Klientorienterede mål:

Øger forståelsen for klienten og bidrager til den bedst mulige behandling $\quad 68 \%$

Internt bortfald =3, idet kun de 336 arbejdsledere, der havde etableret supervision, skulle besvare spørgsmålet.
}

Egelund, T. \& Kvilhaug, A.: Supervisionens organisering 
stor spredning i arbejdsledernes tilkendegivelser, og kun få enkeltmål finder tilslutning hos næsten alle arbejdslederne. De personlighedsudviklende og personaleplejende mål dominerer i arbejdsledernes vurderinger af supervisionens virkninger, 96 procent af arbejdslederne mener, at supervisionen leder til, at socialarbejderne opnår øget indsigt i sig selv, og 85 procent peger på supervision som et værn mod stress og udbrændthed. Blandt de professionelle mål finder 78 procent af arbejdslederne, at supervisionen har en metodeudviklende effekt, mens kun 32 procent markerer, at supervisionen øger teoretisk og forskningsmæssig viden. 68 procent af arbejdslederne angiver, at klientorienterede mål opfyldes via supervision. Ved bivariat analyse er der ikke forskelle på fordelingen af svarene på kategorierne indenfor forskellige virksomhedsområder.

Arbejdslederne blev desuden spurgt om, hvilke mäl, der tilsigtes med den vejledning, som de som arbejdsledere selv udøver overfor personalet. Fra empirisk forskning om arbejdsledernes vejledning (for eksempel Arnstberg, 1989; Larsson \& Morén, 1988) får man indtryk af, at arbejdsledernes vejledning primært er central i forhold til indskoling af personale i den organisatoriske tolkning og håndtering af virkeligheden. I denne undersøgelse angiver arbejdslederne deres vejledningsmål som bredere, de tilstræber via deres egen vejledning desamme varierede mål, som de mener kendetegner supervisionen. Målene er lidt anderledes vægtet, idet arbejdslederne ved deres ledelsesmæssige vejledning først og fremmest tilstræber at lære personalet arbejdsmetoder, 99 procent af arbejdslederne tilkendegiver, at de lægger vægt på dette. Det kan imidlertid se ud, som om arbejdsledernes vejledning om metode ofte er mere juridisk og administrativ i sin karakter end supervisorers metodetræning, og at vejledningen har som primært sigte at sikre korrekt sagsbehandling. Trods dette kan det dog se ud, som om der kan være nogen overlapning mellem arbejdsleders vejledning om og supervisors supervison af metode. Arbejdslederne tilstræber desuden gennem deres vejledning i højere grad, end supervisorer forventes at gøre, at styrke gruppesamarbejdet $i$ arbejdsgruppen, mens personlig udvikling/indsigt i sig selv vægtes lidt lavere af arbejdslederne. Der er således betydelige overlapninger i de mål, arbejdslederne mener den ledelsesmæssige og den supervisionsmæssige påvirkning af personalet skal tilgodese, hvilket også nogle arbejdsledere tilkendegiver. 20 procent mener, at der er overlapning mellem arbejdslederens og supervisors arbejde, 32 procent mener, at der i nogen grad er det, mens 40 procent ikke mener det er tilfældet (8 procent ved ikke). Det tilkendegives ikke, at der opstår problemer af denne overlapning, 96 procent af arbejdslederne finder ikke, at arbejdsdelingen mellem arbejdsledere og supervisorer er problematisk.

Sammenfattende viser resultaterne, at arbejdslederne mener, at supervisionen opfylder et flertal af formål. Der er dog en klar tendens til, at arbejdslederne lægger mest vægt på personlighedsudviklende og personaleplejende formål, og det er også disse formål, de mener, at supervisionen bedst realiserer. Metodeudviklende formål med supervisionen gives også megen vægt af arbejdslederne, mens teori- og forskningsformidling efter arbejdsledernes opfat- 
telse kun i begrænset omfang finder sted i supervisionen. Målformuleringer, der peger på direkte klientorienterede hensigter med supervisionen, er lidt mere sparsomme, men mange arbejdsledere finder alligevel, at supervisionen har en direkte klientrettet effekt, omend mindre end dens personlighedsudviklende/ personaleplejende og metodeudviklende effekter.

\section{Arbejdsledernes vurdering af deres egen indsats $i$ forbindelse med supervision}

Arbejdslederne blev spurgt, hvad de fandt, deres egen rolle i supervisionsprocessen var. De fleste arbejdsledere anser det for deres opgave ${ }^{20}$ at forhandle løn og ansættelsesvilkår med supervisorer (75 procent), at tage initiativ til supervisionen (66 procent), og at godkende valget af supervisorer (64 procent), altså opgaver af mere administrativ karakter. Yderligere markerede mange arbejdsledere, at de har til opgave at evaluere supervisionen enten sammen med personalet alene (66 procent), eller sammen med både personale och supervisor ( 62 procent). 54 procent af arbejdslederne så det som deres opgave at orientere supervisor om organisationens mål og prioriteringar. 40 procent af arbejdslederne mente, at de skulle deltage igruppesupervision. En minoritet af arbejdslederne mente, at de overfor supervisor skulle påpege de specifikke kvalifikationer, som organisationen ønskede styrket (24 procent), diskutere supervisionen

20 De høje procenttal skyldes, at arbejdslederne i dettespørgsmål havde mulighed for at afkrydseså mange svaralternativer, som de fandt relevante. med supervisor under supervisionens gang (17 procent) eller alene sammen med supervisor evaluere supervisionens resultater (30 procent).

I et supplerende spørgsmål blev arbejdslederne spurgt, om de ifølge den aktuelle supervisionskontrakt skulle deltage i evalueringen af supervisionen. 45 procent af arbejdslederne svarer ja, 26 procent svarer nej og 29 procent ved det ikke. Dvs. at knap halvdelen af arbejdslederne ved, at de skal evaluere forløbet. Man kan få indtryk af, at supervisionen i en del tilfælde betragtes som de superviseredes anliggende, som organisationen ikke med selvfølgelighed bør have indsyn i. Dette er overraskende i tider, hvor evaluering af socialtjenestens aktiviteter er et centralt policyspørgsmål.

Sammenfattende tegner dette et billede af, at arbejdslederne primært varetager de administrative aspekter af supervisionen og i mindre grad påvirker indholdet af supervisionen ved for eksempel at påpege, hvilke kvalifikationer organisationen ønsker styrket. Der skabes også et billede af, at supervisionen betragtes som personalets domæne mere end organisationens. Relativt få arbejdsledere overvejer således at diskutere supervisionen med supervisor under supervisionens gang eller ved en afsluttende evaluering, med mindre personalet også deltager. Det virker som en underforstået forudsætning, at det, der foregår i supervisionen, er en sag mellem supervisor og personale, med mindre arbejdslederen selv som superviseret sidder med i supervisionslokalet. Det er alt i alt en relativt administrativ og marginel position, arbejdslederne tildeler sig selv i forhold til at påvirke indholdet $i$ et vigtigt kompetenceudviklingsredskab i

Egelund, T. \& Kvilhaug, A.: Supervisionens organisering 


\section{Tabel 3}

Den formelle og uformelle policys indhold

$\begin{array}{lrr} & \text { Formel } & \text { Uformel } \\ & \mathrm{N}=94 & \mathrm{~N}=190 \\ \text { Policy om supervisionens nødvendighed/selvfølgelighed } & 50 \% & 47 \% \\ \text { Policy om supervisionens omfang og rammer } & 21 \% & 16 \% \\ \text { Policy om supervisionens indhold/metode } & 20 \% & 19 \% \\ \text { Policy om flere af ovenstående aspekter } & 3 \% & 13 \% \\ \text { Andet } & 6 \% & 5 \% \\ \end{array}$

praksis og til at følge dets virkninger op. Tengvald, Bergström \& Sterky (1999) tegner et lignende billede (i forhold til kommunernes kvalitetsarbejde) af en arbejdsledelse, der er velinformeret om arbejdets administrative forudsætninger, men mindre orienterer sig mod arbejdets indhold og resultater.

\section{Handledningspolicy}

Et andet mål på supervisionens integrering i organisationens udviklingsbehov er forekomsten af policyformuleringer om supervision og supervisionens indhold. En policyformulering om supervision kan ses som en indikator på organisationens/kommunens strukturelle ramme omkring og bevidsthed om, hvad supervision skal tjene til. Der blev både spurgt, om der forelå en formel og en informel policy. Resultaterne viser, at. 23 procent af arbejdslederne angiver, at der findes en formel policy for deres ledelsesområde, 46 procent angiver, at en informel policy er gældende. Virksomhedsområdet børn og unge har totalt set oftere formuleret en (formel eller informel) policy for supervision end de andre virksomhedsområder ${ }^{21}$.

21 Destore byer og kommuner med over 30.000 ind-
Formel policy handler for halvdelens vedkommende om at konstatere, at supervision skal tilbydes. Det næsthyppigste er, at policy om supervision drejer sig om administrative aspekter (for eksempel om omfang og ressourceforbrug). Ca. 1 af 5 arbejdsledere angiver, at der eksisterer en policy om indholdet i supervisionen (for eksempel at supervisionen skal indlære en bestemt arbejdsmetode). Med hensyn til informel policy ser billedet nogenlunde ligesådan ud. Dog fokuserer man hyppigere på flere aspekter samtidigt i en uformel policy. Policyformuleringers indhold fordeler sig som $\mathrm{i}$ tabel 3 således:

Sammenfattende angiver en majoritet af arbejdslederne, at en eller anden form for policy foreligger. Policy vedrører dog ofte administrative forhold, for eksempel omfanget af supervision, og sjældenere indholdsmæssige retningslinier, der præciserer, hvilken kvalifikationsudvikling, supervisionen skal tjene.

byggere har dobbelt så ofte en formel policy om supervision som kommuner med under 30.000 indbyggere, mens der ikke er forskel på de tre strata for så vidt angår uformel policy. 


\section{Diskussion}

Der er mange forskellige kategoriseringer af supervisionens opgaver. I psyko-terapeutisk supervision skelnes ofte mellem målorienteret og procesorienteret supervision (Hall, 1981). Den målorienterede supervision sigter på at integrere teoretiske og praktiske kundskaber, så den superviserede sættes i stand til at anvende kundskaberne effektivt i sit professionelle arbejde. Procesorienteret supervision koncentreres om relationen mellem supervisor og den superviserede med henblik på at udvikle den superviseredes personlighed og identitet som terapeut (Ekstein \& Wallerstein, 1977). Lignende kategoriseringer genfindesi litteratur om supervision i socialt arbejde, hvor der ofte tales om klient-, metode- og procesorientering i supervisionen. Klient- og metodeorienteret supervision modsvarer den målorienterede supervision og sigter på at udvikle kompetencen til at analysere klienters situation og integrere effektive arbejdsredskaber. Proceshensigten er den samme i psykoterapeutisk som i socialt arbejdes supervision. Angelsaksisk supervisionsteori (Kadushin 1974 og 1976; Reynolds, 1942; Robinson, 1936, Vargus, 1977) tillægger supervision 3opgaver: en undervisende (som kan sammenlignes med målorienteret supervision), en støttende(som har processigte) og en administrativ. Den administrative opgave udmøntes $i$, at supervisionen skal sikre det sociale arbejdes kvalitet og garantere en effektiv serviceformidling og ressourceanvendelse i overensstemmelse med organisationens mål og hensigter ${ }^{22}$. Den under-

22 I den administrative opgave indbefattes også i visende opgave har i praksis oftest været orienteret mod indlæring af caseworkmetode $i$ en slags mester-lærling relation (Munson,1981), og den støttende opgave antager i flere formuleringer en næsten terapeutisk karakter i overensstemmelse med caseworks psykoanalytiske teorigrundlag (Gardiner, 1989).

Svenske formuleringer af supervisionsteori for socialt arbejde (Bernler \& Johnsson, 1993; Gerdman, 1989; Lundsby \& Sandell, 1981; Pertoft \& Larsen, 1991) adskiller sig fra amerikanske ved, at der tages afstand fra supervision som et organisatorisk (kontrol)redskab og lægges hovedvægt på at fremme en professionel udviklingproces via de støttende og undervisende opgaver. Målet er at udvikle den enkelte socialarbejders profesionelle kyndighed og evne til at bruge sig selv som redskab i arbejdet på en professionel måde (via empati, indsigt i sig selv m.m.).23. Man kan - i forhold til amerikanske supervisionsmodeller-sige, at

\footnotetext{
klassisk supervisionsteori, at supervisionen skal kontrollere kvaliteten af det enkelte personalemedlems arbejde. Kadushin (1974) og Stevenson \& Parsloe (1979) påpeger dog på empirisk grund, at supervisorer gerne underbetoner denne kontrol med kvaliteten af service og det enkelte personalemedlems arbejde. "Accountability" er ifølge disse studier den opgave, supervisorer i praksis lægger mindst vægt på at løfte. Der tages i svenske formuleringer eksplicit afstand fra den del af supervisionens administrative opgave, som vedrører kontrol med kvaliteten af de superviseredes arbejde.

23Supervisionens støttende og undervisende opgaver er i svenske formuleringer imidlertid indholdsmæssigt ikkevæsensforskellige fra deangelsaksiske. De psykosociale modeller (for eksempel Bernler \& Johnsson, 1988 b), supervision
} 
supervisionen sigter mere på den enkeltes integreret personlige/professionelle udvikling end på opfyldelsen af eksplicitte socialpolitiske og organisatoriske mål.

\section{Supervisionens administrative/organisator-} iske aspekter. Af denne undersøgelses resultater ser det ud, som om svenske teoretiske formuleringer af supervisionens opgaver har fundet fodfæste i kommunernes opfattelse af supervision i den forstand, at der ikke ledelsesmæssigt efterspørges en supervision, der er forankret i eksplicitte organisatoriske forventninger eller krav til kvalifikationsudviklingen. Supervisionen ser ud til at være løst koblet til de strategier, kommunerne hver for sig måtte have for udvikling af arbejdet med specifikke klientgruppers særlige problemer.

For dette taler den lidt administrative og tilbagetrukne ledelsesrolle i forhold til at påvirke supervisionens indhold og evaluere dens resultater. Det virker som om, at bestemmelse af supervisionens indholdsmæssige profil primært opfattes som en del af personalets "velerhvervede rettigheder ${ }^{24}$ og et anliggende for supervisor og personale

skal tjene til at forstærke, har hentet inspiration fra amerikansk casework (se også Heap, 1979), og der lægges vægt på at indlære en psykosocial arbejdsmetode og opnå en professionel holdning, der i vid udstrækning er defineret som bevidsthed om sig selv og om de serviceidealer, der normativt styrer socialt arbejde.

24 I de mange telefonsamtaler vi har haft med arbejdsledere for for eksempel at komplettere spørgeskemaerne, bekræftes indtrykket af, at supervision hører til personalets velerhvervede rettigheder, kvalitativt. Mange arbejdsledere har formuleret sig i termer af for eksempel "personalet ejer supervisonen". i forening. For dette taler også, at ledelsen relativt sjældent har lagt vægt på supervisorers formelle kvalifikationer, for eksempel deres kyndighed i en bestemt teoretisk referenceramme og den arbejdsmetode, der knytter sig hertil. Supervisorer udvælges oftere ud fra mere upræcise kriterier ${ }^{25}$, der er orienteret mod kendskab til socialforvaltningsarbejde og supervisors personlige kapacitet og udstråling. Endelig indeholder relativt få policyformuleringer tilkendegivelser af supervisionens indholdsmæssige mål.

Sammenfattende peger undersøgelsens resultater på, at supervision er løst koblet til organisationens eventuelle udviklingsstrategier, og at arbejdslederne i begrænset omfang bruger supervision som et offensivt organisatorisk instrument, rettet mod en specifik kompetenceudvikling i forhold til særlige målgrupper af klienter.

Man kan yderligere spørge, om det hæmmer mulighederne for at anvende det, man som socialarbejder lærer i supervisionen, at arbejdslederne ser ud til at holde sig på sidelinien af supervisionens indhold og resultater. Ifølge Gregoire, Propp \& Poertner (1998) viser en række empiriske undersøgelser, at nogle vigtige forudsætninger for,

25 Belardi (ikke dateret) omtaler ud fra tyske erfaringer den modsætning, at mange supervisorer som selvstændige erhvervsdrivende har en interesse i at præsentere deres kvalifikationer som "all-round" og hævet over konteksten, mens feltet har brug for "field-specific specialisation" (ibid:10). Han finder, at det fører til et "kvalitetstab« (ibid:12), hvis udbuddet af supervision bliver for uspecifikt og ude af trit med de specielle kundskabsbehov, som forskellige områder af socialt arbejde hver for sig har. 
at man anvender den indlærte kundskab fra forskellige typer af efteruddannelse ${ }^{26} \mathrm{i}$ socialt arbejdes praksis, er, at det er klart præciseret, hvad uddannelsen skal handle om, og hvilke arbejdsopgaver, den retter sig mod, samt at arbejdspladsen giver rammer (ledelsesstøtte, tid og muligheder) for, at socialarbejderen efterfølgende kan eksperimentere med og integrere de nye kundskaber. Begge disse forudsætninger kan være vanskelige at leve op til, når supervisionen ikke præciseres indholdsmæssigt, og arbejdsledere nogle gange måske har begrænset viden om, hvilke kundskaber, der skal følges op og gives ledelsesstøtte til.

Supervisionens undervisende opgaver. En stor del af arbejdslederne finder, at supervisionen opfylder undervisende formål. Indholdet i de undervisende opgaver er primært metodeudviklende. Det er imidlertid af arbejdsledernes svar ikke muligt at præcisere hvilke metodiske færdigheder supervisionen i særlig grad styrker, fordi metodekyndighed efterspørges mere uspecifikt gennem supervisors kendskab til IFO eller egen praksis. Da metoder i socialt arbejde i almindelighed er usikre, omtvistede og uudforskede, kan man på denne baggrund være usikker på, hvilke metodiske færdigheder supervisionen faktisk lærer det superviserede personale. Den undervisende opgave omfatter også støtte til at forstå og analysere konkrete klienters situation og problemstil-

26 Gregoire, Propp \& Poertner (1998) anvender begrebet "training",som bådekan omfattekurser af mere kognitiv karakter og metodeindlæring. Forfatterne konstaterer på empirisk grund, at op til 90 procent af det, der indlæres via efteruddannelse i socialt arbejde, ikke anvendes i praksis. ling bedre, mens mere generel formidling af ny viden og forskning ${ }^{27}$ ifølge arbejdslederne $i$ relativt begrænset omfang er en integreret del af supervisionen.

Supervisionens støttende (eller procesorienterede) opgaver. Arbejdsledernes målformuleringer peger på, at de tillægger supervisionens støttende eller procesorienterede opgaver størst effekt. Indholdet i de støttende opgaver har dels det aspekt, at personalet aflastes i forhold til opslidende og traumatiserende dele af arbejdet (forebyggelse af stress og udbrændthed), og dels at personalet udvikler en større indsigt i sig selv med det sigte, at de bliver i stand til at håndtere arbejdets konflikter på en mere professionel måde. For socialarbejdere på det udøvende niveau omfatter arbejdet et dagligt møde med mennesker i nød. For at kunne klare dette kræves både teoretisk og praktisk kundskab og emotionel støtte. Hvis man skal kunne lytte, forstå og berøres af klienternes udsathed, er det et legitimt krav selv at blive lyttet til, forstået m.v., når ens arbejde sættes under lup. Ellers eksisterer der en risiko for, at klienter afvises, behandles ureflekteret, unødigt udsættes for tvang m.v.

Der er naturligvis ikke vandtætte skodder mellem støtte og udvikling af selvindsigt på den ene side og klient- eller metodeorienterede elementer på den anden. Udvikling af selvindsigt kan også have klient- og

27 Belardi (uden datering:11) finder, at supervision hører til "the phenomenological and interpreting consultation procedures", som man "kun kan forstå, hvis man tager del i dem", og dette fænomenologiske kendetegn betyder efter hans opfattelse, at man kan betvivle supervisionens "scientific character".

Egelund, T. \& Kvilhaug, A.: Supervisionens organisering 
metodeorienterede effekter, for eksempel i supervision af vanskelige børnesager, hvor en væsentlig opgave i supervisionen kan være, at socialarbejderen bringes til at se familiens situation klarere og ufarvet af egne familieerfaringer. Det er dog tankevækkende, at støtte og processigte vejer så tungt i supervisionen. Man kan spørge om, hvilke organisatoriske aktiviteter ud over supervisionen, der sigter på at nedbringe stressbelastningen og yde et frirum til reflektion over egne/kollektive reaktioner på arbejdets konflikter? Hvis ikke sådanne andre aktiviteter forefindes, forekommer det forståeligt, at presset på at bruge supervisionen til disse formål bliver stort i et krævende og konfliktfyldt arbejdsfelt. Måske så stort at supervisionens i snævrere forstand kompetenceudviklende (kundskabsformidlende og metodeudviklende) mål, som også er nødvendige for at kunne magte arbejdet, får mindre plads. Derved kan supervision snarere få karakter af en mentalhygiejnisk aktivitet fremfor en aktivitet, der betoner kompetenceudvikling i hele klientarbejdets bredde.

Der kan næppe ud fra denne undersøgelse rejses tvivl om, at supervisionen trods dens relative løskobling fra organisatoriske mål - opfattes som organisatorisk betydningsfuld, når der stilles supervision til rådighed for så mange personalemedlemmer. Det er derfor relevant at spørge om, hvad supervisionens organisatoriske funktion er? Denne undersøgelse kan ikke besvare dette spørgsmål, men der kan ud fra resultaterne rejses nogle spørgsmål til diskussion og eventuel senere udforskning.

Man kunne rejse det spørgsmål, om en for organisationen vigtig funktion er den støttende, der kan bringe personalemedlemmer ud af perioder af oplevet "forurening", opgivelse og følelse af udslidthed og bibringe nogen energi til at arbejde videre med et grundlæggende vanskeligt, modsætningsfuldt og utydeligt job?

Der tegner sig i denne undersøgelse et billede af supervision i svenske kommuner, der først og fremmest byder personalet på muligheder for at præsentere de konflikter og problemer, de er kørt fast i, føler sig overvældede af eller synes er specielt vanskelige. Disse konflikter trækkes ud af den daglige sammenhæng, hvori de indgår (og ud af de relationer, hvori de udspilles), og ind i supervisionslokalet. Dér mødes konflikterne dels af personlig støtte, der betyder, at socialarbejderen kan orientere sig bedre i og orker at gå videre med konflikterne; dels af analyse af socialarbejderens personlige beredskab til at møde konflikterne; og dels i udvikling af metodiske færdigheder $i$ at håndtere problemer af den præsenterede art. I dette billede af supervision øjner man en "personliggørelse" af det sociale arbejdes hovedkonflikter ${ }^{28}$. Grundlaget for konflikter i socialt arbejde kan være mangeartet. Problemer i socialt arbejde kan naturligvis have rod i socialarbejderens belastende arbejdsforhold, person eller metodeusikkerhed. Konflikter kan imidlertid også have rod i for eksempel organiseringen af arbejdet, mangelfulde socialpolitiske ressourcer og virkemidler, et svagt kollektivt kundskabsgrundlag m.m. (Sunesson, 2000). Det kan se ud,

28 „Personliggørelsen« kan bygge på det, Dreier (1993) kalder en af socialt arbejdes både ældste og mest uudforskede doktriner om, at det vigtigste arbejdsredskab i socialt arbejde er socialarbejderens egen person. 
som om supervisionen blandt disse mange mulige drivkræfter til konflikter hovedsageligt fokuserer på socialarbejderens psykiske arbejdsmiljø, personlige forudsætninger og metodeusikkerhed. Man kan på denne baggrund også rejse det spørgsmål, om organisationen "personliggør" konfliktløsning i et multifaktorielt konfliktfelt?

Der er også grund til at spørge om, hvilken funktion supervisionen har for personalet? Selve det, at så mange modtager supervision, indicerer en aktiv interesse for og udbredt accept af supervision som en integreret del af arbejdsudøvelsen. Det samme gør personalets aktivitet i udvælgelses- og ansættelsesproceduren.

Belardi (uden datering) refererer til en række tyske undersøgelser af "brugerundersøgelses»-karakter, i hvilke socialarbejdere er spurgt om deres tilfredshed med supervision. Tilfredsheden er gennemgående stor, og Belardi konkluderer ud fra disse undersøgelser, at "supervision has primarily a positive effect on the social workers in the psycho-hygienic respect. The effect is less regarding the work with the clients and has hardly one on the organizational structure" (Ibid:12). Betoningen af supervisionens støttende og personlighedsudviklende effekter i denne undersøgelse, kunne give støtte til Belardis konklusion. For personalet kan supervisionen være et frirum - måske det eneste - til reparation, (selv)refleksion, øvelse og udvikling. Supervisionen kan være den aktivitet, der giver muligheder for at hæve sig op over dagliglivets mange krævende detaljer, tænke over dem, fåstøtte til dem, sætte dem i relation til egne kræfter og lære at mestre dem bedre?
Supervisionen kan også være et frirum i den forstand, at personalet i nogen udstrækning bestemmer indholdet selv i samarbejde med en supervisor, de har tillid til og deltaget i udvælgelsen af. Resultaterne sandsynliggør, at supervision i nogen grad opfattes som en "velerhvervet rettighed", hvis udformning og indhold personalet har betydelig indflydelse på. I en arbejdshverdag, der på mange måder er udefra bestemt, kan dette måske i sig selv have en værdi og opfattes som et personalegode. Selve det at kunne deltage i udformningen af støtten til det daglige arbejde kan måske i sig selv have en vigtig personaleplejende funktion?

Supervision af et ikke ubetydeligt omfang (mindst 100 timer) er for nylig blevet fastslået som kriterium for at opnå den af SSR internt bevilgede autorisation. Dermed bliver supervision et direkte led i en professionaliseringsstrategi og får det dobbelte formål både at øge den enkeltes kompetence (professionalisme) og at muliggøre kundskabskonsumption med henblik på autorisation (professionalisering ${ }^{29}$ ). Supervision har dermed fået en privilegeret position blandt andre efter- og videreuddannelsesformer, og man må antage, at denne placering i det kollektive professionaliseringsprojekt kan betyde, at socialarbejdere også fortsat vil lægge vægt på, at supervision får en central placering i efter- og videreuddannelsestilbuddene i IFO?

\footnotetext{
29 Svensson(1998)anvender denne skelnen mellem professionalisme, som er den individuelle dygtiggørelse, og professionalisering, som er en faggruppes kollektive krav på legitimitet, begrundet i besiddelse af særskilt specialiseret kundskab.
}

Egelund, T. \& Kvilhaug, A.: Supervisionens organisering 
Det kan således se ud, som om supervision udgør et frirum, der opfylder multiple formål for organisation og ansatte, trods løskoblingen fra eksplicit formulerede organisatoriske mål om kompetenceudviklingens retning. For organisationen kan supervision byde på reduktion af stressniveauet i medarbejdergruppen, udvikling af den enkeltes personlige/faglige evne til konfliktløsning $\mathrm{i}$ dagligdagen og metodisk træning $\mathrm{i}$ at håndtere vanskelige situationer. For medarbejderen kan supervision udgøre et frirum og en støtte til (selv)refleksion, mestring af belastninger i hverdagen, indflydelse på kompetenceudviklingens indhold og formel kvalificering i autorisationsøjemed.

\section{Summary \\ The organization of supervision}

This article deals with supervision of Swedish municipal social work, based upon a survey of 70 municipalities representative of Sweden as a whole. Questionnaires were sent to 478 middle managers (responsible for child protection, social work with substance abusers, and delivery of cash benefits), 412 of whom ( $86 \%$ ) returned the questionnaires.

The article analyses to what extent supervision is used in municipal social work; on what criteria and by whom supervisors are selected and employed; which qualifications are actually considered strengthened by supervision; and the extent to which municipal social agencies clarify the aims of supervision in policy documents.

Resultsindicate that supervision is extensively used as a qualification-developing strategy in Swedish municipal social work, $81 \%$ of social workers receiving supervision at the time of the enquiry. Although this kind of postgraduate training is given priority in municipal social work, results do not indicate that supervision is strongly influenced by organizational objectives. Ordinary staff members seem to exert as much influ- ence on choosing and employing supervisors as do middle managers. The criteria on which supervisors are singled out tend to be imprecise and unsuitable for targeting the development of qualifications according to organizational needs. Middle managers, thus, seem to prefer supervisors' unspecific practice experiences and personal characteristics to formal qualifications (supervisors' training, specific theoretical/ methodological knowledge and orientation etc.).

Middle managers seldom interfere with the content or direction of the supervision. According to their responses, middle managers' relationship to supervisors is of an administrative kind; they do not specify organizational needs to be met by supervision or demand specific theoretical and methodological skills of importance to social work with specific client groups. Nor do they very often evaluate the outcome of supervision.

Managers indicated that the most important objectives fulfilled by supervision are prevention of stress and burn-out and obtaining insight into oneself as a crucial 
work tool. This means that staff care and personal development are given high priority in supervision. Managers also stress the development of methodological social work skills as an important objective of supervision, while they do not consider information on theoretical knowledge and new research findings to be an integral part of supervision. Managers more seldom indicate that client-oriented objectives are an important part of the aims of supervision.

Half of the municipalities offering supervision have formulated some kind of formal or informal supervision policy. Mostly, however, the policy deals with administrative matters (i.e. frequency and length of supervision sessions); only approximately $20 \%$ of policy documents concern the content of the supervision.
It is argued that supervision of Swedish municipal social work seems to be loosely coupled to organizational needs and strategies. Management tend to understand supervision primarily as a staff caring and a personality developing activity, somehow comparable toasupportive therapeutic activity. That is not to say that supervision is considered devoid of educational potential. Especially development of methodological skills is understood as an integral part of supervision, though it is not considered as important as emotional support. The controlling and accountability-securing aspects of supervision, as stressed by Anglo-Saxon supervision theory, is not considered crucial in Swedish supervision of municipal social work.

\section{Litteratur}

Arnstberg, K.-O. (1989) Socialarbetare. Lund: Studentlitteratur.

Austin. L. N. (1963) "The Changing Role of the Supervisior" i Parad, H.J. \& Miller, R.R. eds: Ego-Oriented Casework. Problems and Perspectives. New York: Family Service Association of America.

Belardi, N., ikke dateret, Social Work supervision in Germany. Upubliceret paper.

Bergmark, ̊. \& Lundström, T. (1998) Socialhögskolorna och metoder i socialt arbete. Socionomens Forsknings-Supplement, Socionomen 2, 1998: 67-81.

Bernler, G. \& Johnsson,L. (1988a) Gerhandledning resultat? En process- och effektstudie av handledning $i$ psykosocialt arbete. Göteborg: Rapport 188:1, Institutionen för socialt arbete, Göteborg Universitet.

Bernler, G. \& Johnsson, L. (1988 b) Teori för psykosocialt arbete. Stockholm: Natur och kultur.

Bernler, G. \& Johnsson,L.(1993) Handledningipsy- kosocialt arbete. Stockholm: Natur och kultur. Dellgran, P. \& Höjer, S. (1999) Kunskapandets villkor och gestalt. En studie av uppsatser $i$ socionomutbildningen 1977-97. Stockholm: CUSskrift 1999:1, Centrum för utvärdering av socialt arbete, Socialstyrelsen.

Dreier, O. (1993) Psykosocial behandling. En teori om et praksisområde. København: Dansk psykologisk forlag.

Egelund, T. (1999) Analyse af handlederuddannelserne $i$ Göteborg, på Sköndal og i Umeå. Stockholm: CUS-skrift 1999:6. Centrum för utvärdering av socialt arbete, Socialstyrelsen.

Ekstein, R. \& Wallerstein, R.S. (1977) Handledning och utbildning i psykoterapi. Stockholm: Natur och kultur.

Forslin, E. (1986) Socialsekreterarnas behov av handledning. Stockholm: Svenska Kommunförbundet.

Fryk, L. \& Skårner, A. (1983) "Skit i traditionerna" - en utvärdering av handlederutbildningen $i$

Egelund, T. \& Kvilhaug, A.: Supervisionens organisering 
psykosocialt arbete vid institutionen för socialt arbete $h t 82-v t 83$. Göteborg: Institutionen för socialt arbete, Göteborg Universitet.

Gardiner, D. (1989) The Anatomy of Supervision. Developing Learning an Professional Competence for Social Work Students. Stony Stratford: The Society of Research into Higher Education \& Open Univeristy Press.

Gerdman, A. (1989) Klient, Praktikant, Handledare-om att utveckla en egen yrkesteori. Stockholm: Wahlström \& Widstrand.

Gregoire, T.K., Propp, J. \& Poertner, J. (1998) The Supervisor's Role in the Transfer of Training. Administration in Social Work, Vol. 22(1), 1998: 1-18.

Hall, A. (red.) (1981) Att handleda. Mot utveckling genom utbildning. Stockholm: Psykologiförlaget $\mathrm{AB}$.

Heap, K.K. (1979) Handledning i socialt arbete. Målsättningar för praktiken. Handledarens roll. Metodik och yrkesprinciper. Stockholm: Wahlström \& Widstrand.

Hessle, S. \& Höjer, K. (1979) Handledning och psykosocialt arbete, en diskussion utifrån utvärdering av en utbildning. Stockholm: Barnbyn Skå, Rapport nr 47.

Kadushin, A. (1974) Supervisor-supervisee: a survey, Social Work, May 1974: 288-297.

Kadushin, A. (1976) Supervision in Social Work. New York: Columbia University Press.

Larsson, H. \& Morén, S. (1988) Organisationens mänskligainsida. Omdet sociale arbetetsutvecklingsmöjligheter. Umeå: Department of social welfare, Umeå Universitet.

Lundsbye, M. \& Sandell, G. (1981) Handledning i psykosocialt arbete, Socialmedicinsk tidsskrift,
Nr 10: 569-578.

Munson, C.E. (1981) Style and Structure in Supervision. Journal of education for Social Work, Winter 1981, vol. 17, No. 1: 65-72.

Pertoft, M. \& Larsen, B. (1991) Grupphandledning med yrkesverksamma. Stockholm: Almqvist \& Wiksell.

Reynolds, B. C. (1942) Learning and Teaching in the Practice of Social Work. New York: Farrar \& Rinehardt, Inc.

Robinson, V.P. (1936) Supervision in Social Case Work. Chapel Hill: The University of North Carolina Press.

Stevenson, O. \& Parsloe, P., eds. (1979) Social Service Teams: The Practitioner's View. London: Her Majesty's Stationery Office.

Sunesson, S. (2000) Dilemmas in Practice and Professionalisation - A few pages to welcome ayoung colleague. Lund: (artikel under publicering).

Svensson, L. G. (1998) Socionomernas profession och organisation. Stockholm: (artikel i antologi under forberedelse), CUS.

Tengvald, K., Bergström, M. \& Sterky,E. (1999) Kvalitetsarbete i socialtjänsten. En nationell kartläggning. Stockholm: CUS-skrift 1999:7, Centrum för utvärdering av socialt arbete, Socialstyrelsen.

Vargus, I. D. (1977) "Supervision in Social Work» i Kurpius, D. J., Baker, R. D. \& Thomas, I. D., eds.: Supervision of Applied Training. A Comparative Review: 153-182. Westport, London: Greenwood Press.

Wigzell, K. \& Pettersson, L. (1999) Socialtjänsten ska baseras på vetenskap och beprövad erfarenhet. Socionomen, 2/2000: 18-20. 